\title{
Comparison of Task Repetition and Task Sequencing in Terms of Their Effects on L2 Students' Oral Performance ${ }^{1}$
}

\author{
Richard Cheng Ching Ho
}

Hang Seng Management College, Hong Kong, chengchingho27@yahoo.com.hk

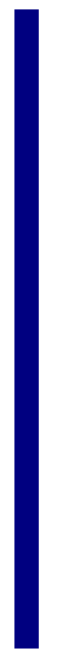

Task-based teaching is a popular topic in education field, since there is an increasing numbers of learners trying to learn their second language. However, by using the traditional drill practice, learners can only learn the rules, rather than using the language in the reality. Therefore some scholars have come up with a more communicative and learner-centered approach of teaching. In task-based teaching, students will be given a more realistic situation for them to learn the target language. Moreover, they can have more time to discuss and come up with a collaborative answer. Overall, students can think of their own answers towards different topics. In this paper, the focus will be on comparing task repetition and task sequencing. I would like to see which method will lead a better improvement based on students' performance. In this research, 40 Hong Kong tertiary students were participated in an English speaking course, and they were all non-language major students. Those students have been divided into 2 groups, and they had been divided into two different teaching methods classes named as task repetition and task sequencing. During the six-week course, students needed to submit their recordings in class. Their recordings were being codified and analyzed after each lesson.

Key Words: task repetition, task sequencing, task performance, oral performance, student's performance

\section{INTRODUCTION}

In the past few decades, there is a change of teaching method in Hong Kong and the second language learning approach has changed from presentation, practice and production (PPP) to a more communicative approach in teaching. Task-based language teaching (TBLT) is a method, which allows learners to participate actively (Hashemi et al., 2012), and they will be given a more realistic situation to learn the target language. In Hong Kong, TBLT has been promoted, and its curriculum and guidelines have been

\footnotetext{
${ }^{1}$ This article has been presented on $1^{\text {st }}$ May, 2016 in Malaysia, and it has been shown in the Conference of Language, Education, Humanities \& Innovation 2016 ( $\left({ }^{\text {rd }}\right.$ ICLEHI).
}

URL: http://www.e-iji.net/dosyalar/iji_2017_1_19.pdf

DOI: $10.12973 / \mathrm{iji} .2017 .10119 \mathrm{a}$ 
changed and reviewed over the last decades (Carless, 2004). TBLT should be learnercentered and it should also develop learners' communicative competence (Curriculum development council, 2007). In TBLT, there are several approaches to teach learners, such as task repetition and task sequence.

Some scholars claim that task repetition can enhance students' accuracy and fluency. This is due to the fact that learners can familiarize themselves with the content of the pervious task (Fukuta, 2015), and then they can formulate their language structure to finish the task in their second performance (Bygate, 2001: Ellis, 2003). Although students may speak fluently, their speech may contain a lot of errors. Willis and Willis (2007) suggested that using a systematic complete task sequence can enhance students' performances such as introducing some common grammatical mistakes during the pretask stage (Doughty and Williams 1998). As a result, students will pay attention to the related details while achieving their tasks (Robinson, 2003).

Both task repetition and task sequencing have relevant researches to evaluate their overall outcomes in students' performance, but there is a lack of research in comparing these two teaching methods' outcomes. Therefore, in this paper, the focus will be on the improvement of those two groups of students, who are being taught in either task repetition or task sequence.

\section{LITERATURE REVIEW}

\section{Definition of Task}

There are several scholars who have put their own definition into task. The most common quote is from Long (1985), who refers task as something that did for others, for example, making an airline reservation. Therefore, "task" is meant something that is done in everyday life (Long, 1985). Based on this definition, scholars further elaborate on the definition of "task". For instance, "task" is used in the classroom, and allows learners to interact or manipulate the target language (Nunan, 1989). Hence, "task" should be primary focus on meaning (Skehan, 1998). As a result, "task" is something that can be used in classroom teaching, and it should be able to create a real purpose for language use (Hashemi et al., 2012). Moreover, the tasks implemented in the lessons should be related to real life settings, so that students can learn within their own area of interest (Hashemi et al., 2012).

\section{Task repetition}

Levelt's (1989) speech production model is the base of how task repetition functions among students. According to Levelt (1989), language production system can be divided into three parts, which are the conceptualizer, the formulator and the articulator. Speaker will start with conceptualizing the information by selecting the related material to be encoded and decided the sequence of the information. After that, the conceptualizer will pass the information to formulator. The formulator will select the appropriate lexical units and use grammatical and phonological rules. Finally, the articulator will articulate the linguistic units as sound. These are the basic processes which undergo by a monolingual speaker, but task repetition allows speakers to finish part of the processes 
in their first performance (Bygate and Samuda, 2005). After finishing some of the steps, some of the materials are stored in memories and they can be reused in the second occasion (Bygate and Samuda, 2005). Therefore, task repetition is useful for learners to improve their performance in their second attempt (Fukuta, 2015).

There are some studies which are related to the effects of task repetition. Bygate (1996) explored the effect of task repetition on L2 cognitive processes. The study required students to watch a video for about a minute and a half, and they were asked to produce their speech immediately (Bygate, 1996). After that, students watched the video for the second time, and they were asked to do the same thing after watching the video second time (Bygate, 1996). The result showed that students could produce more complex sentence structures than previous, and they could reuse the material from the initial experience (Bygate, 1996). This has proven the effectiveness of task repetition on attention to linguistic form (Bygate, 1996).

In another study, Gass, Mackey, Alvarez-Torres and Fernandez-Garcia (1999) have done a similar task as Bygate (1996), but they have repeated the task for four times. The result showed that students' overall performance, such as proficiency, accuracy in morphosyntax, has been increased (Gass et.al, 1999). Students used less common words after repeating the task for four times, which showed that their lexical variety was enhanced (Gass et al., 1999).

Task repetition can also enhance students' fluency and complexity. In a study conducted by Ahmadian and Tavakoli (2011), task repetition was used as a pre-task planning, and it was found that task repetition could bring positive impacts on both complexity and fluency. This was due to the fact that students finished their conceptualizing step in their first performance, so during their second attempt, they did not need to pay much attention to the meaning (Ahmadian and Tavakoli, 2011). Moreover, some of the materials were memorized during the first attempt, and they could be reused in their second attempt (Ahmadian and Tavakoli, 2011).

Overall, there are many positive aspects towards task repetition. The reason that task repetition can enhance students' performance is that students are familiar with the tasks that they are working on. In a study carried out by Sample and Michel (2014), students eliminated the trade-off effect during their third attempt of the target task, and their oral performance increased. This shows that task repetition can help students to familiarize with the task and improve their oral performance.

\section{Task sequencing}

As for task sequencing, scholars mainly focus on form for the input before carrying the task. This can help students to be aware of the form in a specific context (Robinson, 2005) and accomplish the target task successfully (Skehan, 1998). Having task sequencing in teaching can build up a course syllabus for students to learn (Long, 1985). In the past, some scholars proposed that a task-based syllabus should be developed and sequenced, so that it could be relevant to real-world tasks (Robinson \& Ross, 1996). 
Highly-structured approach, such as Willis's framework (1996), can provide ways for teachers to frame up classroom activities, but task-based teaching is more than just using pre-, during- and post-task. With the large range of tasks selection, they should be implemented more flexibly so that they can be adapted to a diversity environment (Norris, 2009). However, feedback is essential during the lesson, such as recasts, brief grammatical explanation (Norris, 2009). Those kinds of feedback can build a greater awareness in language, and they allow learners to use them in practical settings (Norris, 2009).

Since Nunan's opinion (1989) emerged, some scholars have demonstrated that taskbased teaching can focus on form explicitly without affecting the communicative purpose (Swain, 1997). Task sequence can be divided into two groups such as focus on form and focus on meaning, and those sequences have been put into real classroom setting for experiment (Swain, 1998). Students were able to construct the meaning and focus on form while they were performing the task (Swain, 1998). Swain and Lapkin (2001) further proposed in their study that the dictogloss task type would allow students to pay more attention on form rather than the jigsaw task (Pica et al., 1993).

\section{Research Questions}

Based on Ahmadian and Tavakoli's findings in 2011, it can be said that task repetition can enhance students' complexity and fluency. It can be seen that task repetition has more positive effects on students' performance, since this method allows students to repeat and redo the task again (Fukuta, 2015). However, in this paper, I would like to focus on comparing both task repetition and task sequence. Therefore, there are several hypotheses that I would like to discuss in this paper which I hope tcan compare both the outcomes of task repetition and task sequence.

1) Which method is more effective in enhancing students' fluency performance?

2) Which method is more effective in enhancing students' accuracy performance?

3) Which method is more effective in enhancing students' complexity performance?

4) Which teaching method can help students to be aware of the linguistic features, such as grammar?

\section{METHOD}

There were two groups of participants. The first group was using task repetition as the main stream of teaching, whereas the other group was using task sequencing based on Willis's framework (1996).

\section{Participants and setting}

There were 40 participants in this research, and they were divided into two classes, which would be 20 people for each class. The participants were mainly university students, who were not major in English. Due to the fact that English major students may have a bigger advantage in tackling the task, this may affect the whole purpose of this research. The age range of those students was between 18 and 23, and they were learning English as a second language. For the background of the participants, they have 
taken 12 years of English lessons in primary and secondary school. Before the first lesson, they took an IELTS listening test to show their English proficiency level.

The data-collecting procedures were held in a small tutorial classroom in university. The classes had lasted for 6 weeks including the data collection process and students' feedback and discussion session. For the last week (Week 6), students could discuss their thoughts or anything with the teacher and their peers. Students were required to attend the class every week (See Table 1). I had conducted those lessons for 6 weeks, and after every lesson. I collected students' recordings for checking their progress and performance. The tasks were mainly communicative activities, such as picture descriptions, retelling the story, retelling the news and commenting on an issue. All the data was recorded into a recorder, and they were transmitted to the computer for transcriptions and coding.

\section{Design}

The research was conducted using two different experimental classes. The lessons were divided into four categories, but the methods of teaching for both groups were different. Class A consisted of a pre-task session at the beginning and a post-task session at the end, and the task was not repeated in the following week. As for Class B, their task was repeated in the following week (See table 1).

Table 1

Experimental classes

\begin{tabular}{lll}
\hline & Class A (task sequence) & Class B (task repetition) \\
\hline Week 1 (Task 1) & Picture description & Picture description \\
\hline Week 2 (Task 2) & Retelling story & Picture description \& Retelling story \\
\hline Week 3 (Task 3) & Retelling news & Retelling story \& Retelling news \\
\hline Week 4 (Task 4) & Comment on an issue & Retelling news \& Comment on an issue \\
\hline Week 5 & Sum up this workshop & Presentation \& Sum up this workshop \\
\hline Week 6 & Feedback and discussion & Feedback and discussion \\
\hline
\end{tabular}

Due to the fact that those were monologue tasks, students only needed to work by themselves. Those recordings from students were not graded or taken their grade point average (GPA) into account, so students' performance were not forced or controlled. As for the data collecting sessions, the students were asked to record their speaking with their own cellphone or a recorder from the teacher. All of the students, who attended the class, recorded their speaking task during the lesson, and sent it to their teacher in class.

\section{Measures}

In this research, I am focusing on three variables to judge students' performance named as fluency, accuracy and complexity.

The measurement of fluency was obtained according to the number of pauses. The pause was only recognized if it was longer than 0.4 seconds (Skehan, 1998). The measurement of complexity was based on the total number of clauses divided by the total number of AS-units (Foster et al., 2000). An AS-unit was related to a speaker's utterance, which contained an independent clause or sub-clausal unit (Foster et al., 2000). However, the 
utterance should contain a finite verb in order to become an AS-unit. For example, "Peter goes ::: to sleep :;:a . (2 clauses, 1 AS-unit)", using “:::." to signify independent clause, whereas ":;:" to signify dependent clause. As for dependent clause, there were three different types, which were before (b), middle (m) and after (a). The minimum of the complexity score was 1.00.The measurement of accuracy was based on the error clauses divided by the total clauses. Those error clauses contained syntax error clause (err_m_s), pronunciation error clause (err_m_p), morphology error clause (err_m_m) and lexis error clause (err_m_l). If the clause was error free, the coder put errfr to signify an error free clause.

\section{Analysis}

This study used SPSS to organize all the collected data. The data was calculated and compared by using the t-test. Moreover, a task profile programme was used to analyze all the coded files, such as the number of words per minutes, formality, accuracy, complexity. There was also a modified calculator to calculate students' lexical density.

\section{FINDINGS}

To begin with, the scores for accuracy in each class can be seen in table 2. The maximum score for accuracy is 1.00 , and it can show the trends of each group. It can be easily spotted that students' accuracy score fluctuated in Class A, whereas in Class B, it maintained a steady rate between 42 and 48 out of 100 . In order to check whether the means for both groups were statistically significant, an Independent Samples t-test was carried out. The result can be seen in table 3 .

Table 2

Students' overall accuracy performance (means out of 100)

\begin{tabular}{lllll}
\hline Classes & Task 1 & Task 2 & Task 3 & Task 4 \\
\hline A (Task sequence) & 40 & 53 & 37 & 34 \\
B (Task repetition) & 48 & 44 & 45 & 43 \\
\hline
\end{tabular}

Table 3

Independent samples test for class A and B (accuracy)

\begin{tabular}{lll}
\hline & t-test for equality of Means \\
\hline & $\mathrm{t}$ & Sig (2-tailed) \\
\hline Task 1 & -2.265 & .03 \\
\hline Task 2 & 2.263 & .03 \\
\hline Task 3 & -2.117 & .04 \\
\hline Task 4 & -2.154 & .04 \\
\hline
\end{tabular}

It can be seen that all the numbers for both groups were statistically significant. In task 1 , task 3 and task 4, the means of those three tasks in task repetition class were higher than those in task sequence class, and there is only once that task sequence class had a higher score. Generally, when students had more chances to redo the task, their performance improved. However, in task 2, it seems that the students were still adjusting their learning attitudes during class. After the adjustment, in task 3 and 4, task repetition class had the better score. Furthermore, this result can further strengthen the study of Gass et 
al (1999), which showed that by using task repetition, students' accuracy in target language increased. By comparison, this also emphasizes that task repetition can help students to achieve a better accuracy performance in oral.

The second comparison between task repetition and task sequence is on fluency. In this study, students' fluency performance was measured by two variables, which were lexical density and words per minutes (WPM). The maximum score for lexical density was 100 , whereas WPM did not contain any maximum score. WPM depends on the spontaneity of students' oral performance. Table 3 and 4 show the mean score for both classes in lexical density and WPM, whereas table 5 and 6 show the t-test results for both classes.

Table 4

Students' overall lexical density (means)

\begin{tabular}{lllll}
\hline Classes & Task 1 & Task 2 & Task 3 & Task 4 \\
\hline A (Task sequence) & 45.97 & 44.70 & 48.55 & 47.70 \\
B (Task repetition) & 48.86 & 47.88 & 44.87 & 45.08 \\
\hline
\end{tabular}

Table 5

Students' overall words per minutes (means)

\begin{tabular}{lllll}
\hline Classes & Task 1 & Task 2 & Task 3 & Task 4 \\
\hline A (Task sequence) & 89.01 & 84.61 & 82.44 & 79.02 \\
B (Task repetition) & 105.09 & 97.04 & 104.24 & 89.77 \\
\hline
\end{tabular}

Table 6

Independent samples test for class A and B (lexical density)

\begin{tabular}{lll}
\hline & t-test for equality of Means \\
\hline & $\mathrm{t}$ & Sig (2-tailed) \\
\hline Task 1 & -2.197 & .03 \\
\hline Task 2 & -2.151 & .04 \\
\hline Task 3 & 2.857 & .01 \\
\hline Task 4 & 2.784 & .01 \\
\hline
\end{tabular}

Table 7

Independent samples test for class A and B (words per minutes)

\begin{tabular}{lll}
\hline & t-test for equality of Means \\
\hline & $\mathrm{t}$ & Sig (2-tailed) \\
\hline Task 1 & -2.098 & .04 \\
\hline Task 2 & -2.109 & .04 \\
\hline Task 3 & -4.552 & .000 \\
\hline Task 4 & -2.124 & .04 \\
\hline
\end{tabular}

The t-test results show that the numbers for both lexical density and WPM were statistically significant. However we do not know whether students were more fluent in Class B. This is due to the fact that class A's students produced more words than students in class B. Therefore, we cannot really confirm the first hypothesis which we will discuss in the discussion section.

The last finding is about students' complexity performance. The complexity scores were calculated by the number of clauses divided by the total AS units in the text (Foster et al., 
2000). Therefore, the minimum score for each student should be at least 1.00 . Table 7 shows the mean score for both classes, whereas table 8 shows the t-test result.

Table 8

Students' overall complexity performance (means)

\begin{tabular}{lllll}
\hline Classes & Task 1 & Task 2 & Task 3 & Task 4 \\
\hline A (Task sequence) & 1.34 & 1.56 & 1.43 & 1.37 \\
B (Task repetition) & 1.47 & 1.40 & 1.55 & 1.51 \\
\hline
\end{tabular}

Table 9

Independent samples test for class A and B (complexity)

\begin{tabular}{lll}
\hline & \multicolumn{2}{l}{ t-test for equality of Means } \\
\hline & $\mathrm{t}$ & Sig (2-tailed) \\
\hline Task 1 & -2.416 & .02 \\
\hline Task 2 & 2.243 & .03 \\
\hline Task 3 & -2.189 & .04 \\
\hline Task 4 & -2.194 & .04 \\
\hline
\end{tabular}

In table 8 , the t-test shows that the numbers in table 7 were statistically significant. Therefore, in an overall point of view, the trend tends to indicate that class B had a better score than class A. Although in task 2 task sequence, class had a higher score than task repetition, which is similar to the result in Table 3, the students were still adjusting the learning attitude and atmosphere in class. I do not think this is a phenomenon since there is not enough evidence to prove this.

\section{DISCUSSION}

\section{Both teaching methods have their own advantages}

My first hypothesis, which claims that task repetition is a better method in enhancing students' fluency performance, is only partially correct. Students tended to produce more utterance in task repetition class, because they had a second opportunity to reproduce their task. Therefore, class B's students had better scores in WPM than class A's students. However, students could just speak less spontaneous; so their utterances could not contain any meanings. Lexical density can show the text packages of information (O'Halloran, 2005), and it can also justify students' fluency performance accurately. It is quite interesting to find out that the means in lexical density (see table 4) fluctuated among both classes. For the first two tasks, class B had a higher density than class A, whereas for the last two tasks, class A had a better score.

The reason for this phenomenon is due to the familiarity of the topics. In class A, teacher provided some background information during the pre-task section, and this allowed students to have a better in-sight in that topic, especially in Task 3 of retelling the news activity. However, for class B, they did not really have a pre-task section. The only advantage that class B had was allowing them to repeat again. Therefore, students did not have a lot of ideas in tackling or understanding the task. This led to students in class to only base on their experience to perform the task, and their fluency scores became fluctuated. 


\section{Overwhelming results in both accuracy and complexity}

The means scores have provided us with an overwhelming result. In both accuracy and complexity performances, class B's students achieved a better result than class A's students. This further proved that task repetition could enhance students' linguistic performance, because they had a second chance to redo the task (Bygate, 1996; Gass et al., 1999; Fukuta, 2015). There were some linguistic features that students were able to correct and modify in their second attempt.

\section{Extract 1: Class B's student picture descriptions}

I think it want to play with the Bowie because it pick up a ball and go to Bowie side I think it want to play with Bowie. (First attempt)

There is a man who wears the cap is dealing with the bulb decorations but unfortunately the bulb is falling down on the floor. (Second attempt)

Those sentences were extracted from one of the students in class B. It can be clearly seen that she made some grammatical adjustments in her second attempt in picture description.

As for class A's students, most of them often forget those grammatical features, such as third person singular, plural.

\section{Extract 2: Class A's student picture description}

Ken try to fix it out and try to turn the light on but still cannot turn on the light so he try to take a chair under the light and step on it and try to fix the bulb and suddenly there is a dog which is a monkey.

Since they do not have another attempt to the same task, students often regret after they noticed they had made some mistakes in their oral tasks.

As in complexity, students in class B allowed to repeat the same task often had higher scores in complexity. This was due to the fact that they did not need to produce their utterance "on the spot" (O'Halloran, 2005), whereas class A's students needed to speak immediately and could not repeat again. For students in class B, they could treat their first attempt as a rehearsal, and during their second attempt, they tried to modify the nouns or build up their sentences.

\section{Extract 3: Class B's student retelling news}

Hong Kong is afraid for the new dragon baby overload in the coming dragon years the pregnant Mainlanders is keep coming except to travel to Hong Kong to give birth to that dragon baby the dragon is traditionally associated with emperor power. (First attempt)

This is a news about travelling Hong Kong to give birth the news about year of dragon in Fung Shi it's believe that baby who born in year of dragon will have the emperor power and none of this we don't have it emperor power but we still means they will 
have a good fortune and prosperity so not only the mainland China the Hong Kong people they are tend to have baby in this year. (Second attempt)

The above example shows that the second attempt for students can help them to rethink and modify their performance. Moreover, retelling news needs students to use another way to present their information. For example they need to speak in a more formal perspective and they cannot add anything irrelevant into the news. Therefore, students in class A could only produce simple sentences in their task, and this led to low scores in complexity. However, in class B, they had one more chance to redo the task; this allowed them to modify their speech.

\section{Students' awareness in linguistic features}

In my last hypothesis, those students, who studied in task sequence class, should be more aware of those linguistic features, such as grammars or sentence structure. However, the result showed that students in class B, which was the task repetition class, had a better score in grammar accuracy (see table 2). Although students in class A had more time in discussing the linguistic issues in class, they could not use them in reality.

As for class B, they had a more steady score in accuracy compared to class A. However, there was an interesting phenomenon in class B. After their second attempt, students tended to over correct their mistakes in order to meet teacher's expectation. This is similar to Lightbown and Spada (2006) data in overgeneralization errors. Students in class B tended to emphasize the third person singular issue too much, so in their speech, they overused the third person singular "-s" marker.

\section{Extract 4: Class B's student picture description}

Let's looks at the surroundings environment of the house from the picture we can see that it's a television placed on the cardboard while at the middle there is a lamp stands on the floor well from right hand side there are two pictures hangs on the floor

Those errors indicate that students understood the grammatical structure in English, but they overused them. This is a typical phenomenon that happens among L2 speaker. They got confused with their native language, and then they over corrected their mistakes (Lightbown \& Spada, 2006).

\section{Hypercorrection from the students}

Hypercorrection is used to intimate higher status in the society (Holmes, 2008). In this study, this phenomenon happened within the task repetition class. Using Labov's study in 1964 as an example, people tended to overuse the " $r$ " pronunciation, since it could should a sign of prestige in American English (Labov, 1966). In this study, since the task repletion class had another change to redo the task, students tended to overcorrect it in their second attempt. Due to the fact that students would like to please the teacher academically, they tried to overuse the grammatical features that had been learnt in previous lesson. Using extract 4 as an example, that student put "-s" to signify present tense, but he overused the grammatical feature. In education prospective, this can be recognized as overgeneralization, whereas in a sociolinguistics point of view, he tried to 
intimate with the authority. The reason that students overused the feature was that he would like to receive recognition from the teacher, and receive high marks from this task.

\section{CONCLUSION}

To conclude, the result of the study shows that task repetition is a more effective method in enhancing students' accuracy, complexity and fluency. However, in some occasions, task sequence has its own advantages, such as providing more information about the task to students. In some occasions, such as story-telling (Task 2), class A's students could perform better than class B's students in complexity. Therefore, in real classroom situation, teacher should provide enough practice time for students, but also teacher should provide enough background information for students during the per-task stage.

During the experiment, although it was quite obvious that repeating the task could help students to perform better, students' performance could also be affected by other factors, such as teaching methods, teaching environment. Therefore, for example during task 2 , task sequence class had higher scores than task repetition class in accuracy and complexity. However, this still needs further research on this area since there is not enough evidence to prove other aspects affect students' performance.

Another interesting factor is that, this study can reflect some of the sociolinguistics features from the students. For example, they used hypercorrection to please their teacher, and received recognition from the authority. Although this was a common sign from students, researchers did not aware of the psychological change from students' perspective. This can be further proven with more class observation and interviews with students.

\section{REFERENCES}

Ahmadian, M. J., \&Tavakoli, M. (2011).The effects of simultaneous use of careful online planning and task repetition on accuracy, complexity, and fluency in EFL learners' oral production. Language Teaching Research, 15(1), 35-59.

Bygate, M. (1996). Effects of task repetition: Appraising the developing language of learners. In Willis, J., \& Willis, D. (eds.), Challenge and Change in Language Teaching (pp.136-146). Oxford, Inglaterra: MacMillan.

Bygate, M. (2001).Effects of task repetition on the structure and control of oral language. In M. Bygate, P. Skehan, \& M. Swain (eds.), Researching pedagogic tasks: Second language learning, teaching and testing (pp. 23-48).Harlow: Longman.

Bygate, M. \& Samuda (2005). Integrative planning through the use of task repetition. In R. Ellis (ed.), Planning and task performance in second language (pp. 37-74). Amsterdam: John Benjamins.

Carless, D. (2004).Issues in teachers' re-interpretation of a task-based innovation in primary schools. TESOL quarterly, 38 (4), 639-662.

Curriculum Development Council. (2007). English language curriculum and assessment guide. Hong Kong: Hong Kong Government. 
Doughty, C., \& Williams, J. (1998).Pedagogical choices in focus on form.In C Doughty \& J.Williams (Eds.), Focus on form in classroom second language acquisition (pp. 197262). New York: Cambridge University Press.

Ellis, R. (2003). Task-based language learning and teaching. Oxford: Oxford University Press.

Foster, P., Tonkyn, A., \&Wiggleworth, G. (2000). Measuring spoken language: A unit for all reason. Applied Linguistics, 21 (3), 354-375.

Fukuta, J. (2015). Effects of task repetition on learners' attention orientation in L2 oral production. Language Teaching Research.

Gass, S., Mackey, A., Alvarez-Torres, M. J., \&Fernández-García, M. (1999). The effects of task repetition on linguistic output.Language Learning, 49, 549-581.

Hashemi, M., Azizinezhad, M. \&Darvish, S. (2012). Using task-based language teaching, learning practically in English classes. Procedia-Social and Behavioral Sciences, 31, 526-529.

Holmes, J. (2008). An introduction to sociolinguistics. London: Pearson Education Limited.

Labov, W. (1966). The social stratification of English in New York City. Washington, DC: Centre for Applied Linguistics.

Levelt, W. (1989).Speaking: From intention to articulation. Cambridge, MA: MIT Press.

Lightbown, P, M. \& Spada, N. (2006). How Languages are learned ( $3^{\text {rd }}$ Eds). Oxford: Oxford University Press.

Long, M. H. (1985). A role for instruction in second language acquisition: Task-based language teaching. In K. Hyltenstam\& M. Pienemann (Eds.), Modeling and assessing second language acquisition (pp. 77-99).Clevedon, Avon:Multilingual Matters.

Norris, J. M. (2009). 30 Task-Based Teaching and Testing. The handbook of language teaching, 578-595.

Nunan, D. (1989). Designing Tasks for the Communicative Classroom. Cambridge: Cambridge University Press.

O'Halloran, K. A. (2005). Getting Inside English: Interpreting texts. United Kingdom: The Open University.

Pica, T., Kanagy, R. and Falodun, J. (1993). Choosing and using communication tasks for second language instruction. In G. Crooks and S. Gass (eds) Tasks and Language Learning: Integrating Theory and Practice (pp. 9-34). Clevedon, Avon: Multilingual Matters.

Prabhu, N,S. (1987). Second language pedagogy. Oxford: Oxford University Press. 
Robinson, P. (2003). The cognition hypothesis, task design, and adult task-based language learning. Second Language Studies, 21 (2), pp. 45-105.

Robinson, P. \& Ross, S. (1996). The development of task-based testing in English for academic purposes programs. Applied Linguistics, 17, pp. 455-476.

Sample, E., \& Michel, M. (2014). An exploratory effects of complexity, accuracy, and fluency on young learners' oral task repetition. TESL Canada Journal, 31 (8), pp. 23-46.

Skehan, P. (1996). A frame work for the implementation of task-based instruction. Applied Linguistics, 17 (1), 38-62.

Skehan, P. (1996b). Second language acquisition research and task-based instruction. In Willis, J. \& Willis, D. (eds): Challenge and change in language teaching. Shanghai: Shanghai Foreign Language Education Press.

Skehan, P. (1998). A cognitive approach to language learning. Oxford: Oxford University Press.

Swain, M. (1997). The output hypothesis, focus on form, and second language learning. In V. Berry, R. Adamson and W.T. Littlewood (eds) Applying Linguistics (pp. 1-21). English Language Centre: University of Hong Kong.

Swain, M. (1998). Focus on form through conscious reflection. In C. Doughty and J. Williams (eds) Focus on Form in Classroom Second Language Acquisition (pp. 64-81). Cambridge University Press.

Swain, M., \& Lapkin, S. (2001). Focus on form through collaborative dialogue: Exploring task effects. Longman, Pearson Education.

Willis, J. (1996). A framework for task-based learning. Harlow: Longman.

Willis, D. \& Willis, J. (2007).Doing task-based language teaching. Oxford: Oxford University Press. 


\section{Turkish Abstract \\ Konu Tekrarı ve Konu Sıralaması Arasındaki Karşılaştırmanın L2 Öğrencilerinin Sözlü Performanslarına Etkisi}

Konu tabanlı öğrenme, ikinci bir dil öğrenmek isteyenlerin sayısındaki artıştan dolayı eğitim alanında çok popüler bir temadır. Bunula beraber uygulamada geleneksel yöntemleri kullanmak öğrenenlere dili kullanmaktan çok sadece kurallarını öğretebilir. Böylece bazı eğitimciler öğretimde öğrenen merkezli ve daha iletişimsel etkinlikler önermişlerdir. Konu tabanlı öğretimde, öğrencilere hedef dili öğretmek için daha gerçekçi durumlar verilir. Böylece öğrencilerin bu durumu tartışmaya zamanları olur ve öğrenciler ortak çalışmaya dayalı cevaplar önerebilirler. Genel olarak öğrenciler farklı konulara yönelik cevaplarını düşünebilirler. Bu çalışmada konu tekrarı ve konu sıralaması karşılaştırılmıştır. Öğrenci performanslarında hangi yöntemin daha büyük bir gelişmeyi sağladığı araştırılmıştır. Bu araştırmaya İngilizce kursuna kayıtlı ve İngilizce bilmeyen 40 Hong Konglu öğrenci katılmıștır. Öğrenciler 2 gruba ayrılmış; her bir sınıfa konu tekrarı ve konu dizilimi olarak iki farklı öğretim yöntemi uygulanmıştır. 6 haftalık kurs boyunca öğrencilerin sınıftaki etkinlikleri kayıt altına alınmıştır. Bu kayıtlar her bir dersten sonra kodlanıp analiz edilmiştir. Öğrencilerin sözlü performansları akıcılık, zorluk ve doğruluk olmak üzere üç kategoride değerlendirilmiştir.

Anahtar Kelimeler: konu tekrarı, konu dizilimi, konu performansı, sözlü performans, öğrenci performans1

\section{French Abstract \\ Comparaison Entre Répétition de Tâche et Séquencement de Tâche, Les Effets Sur La Performance Orale d'Étudiants L2}

L'enseignement à base de tâche est un sujet popluar dans le domaine d'enseignement, depuis il y a les nombres croissant d'apprenants essayent d'apprendre leur deuxième langue. Cependant, en utilisant la pratique de foret traditionnelle, les apprenants peuvent seulement apprendre les règles, plutôt qu'utiliser la langue dans la réalité. Donc quelques érudits ont inventé une approche plus communicative et centrée sur l'apprenant d'enseignement. Dans l'enseignement à base de tâche, on donnera une situation plus réaliste aux étudiants pour eux pour apprendre la langue cible. De plus, ils peuvent avoir le temps plus de discuter et inventer une réponse collaborative. En général les étudiants peuvent penser à leur propre réponse vers des sujets différents. Dans ce papier, le centre comparera la répétition de tâche et le séquencement de tâche. Je voudrais voir que la méthode aidera une amélioration plus grande basée sur la performance des étudiants. Dans cette recherche, 40 Hong-Kong des étudiants tertiaires ont été participés à un cours de conversation d'anglais et ils étaient étaient tout le commandant de non-langue des étudiants. Ces étudiants ont été divisés dans 2 groupes et ils avaient été divisés dans deux classes de méthodes d'enseignement différentes, qui sont la répétition de tâche et le séquencement de tâche. Pendant le cours de six semaines, les étudiants ont dû soumettre leurs enregistrements dans la classe. Leurs enregistrements étaient codifiés et analysés après chaque leçon. Les performances des étudiants ont été évaluées dans trois catégories, qui sont l'aisance, la complexité et l'exactitude.

Mots Clés: répétition de tâche, séquencement de tâche, performance de tâche, performance orale, la performance d'étudiant 


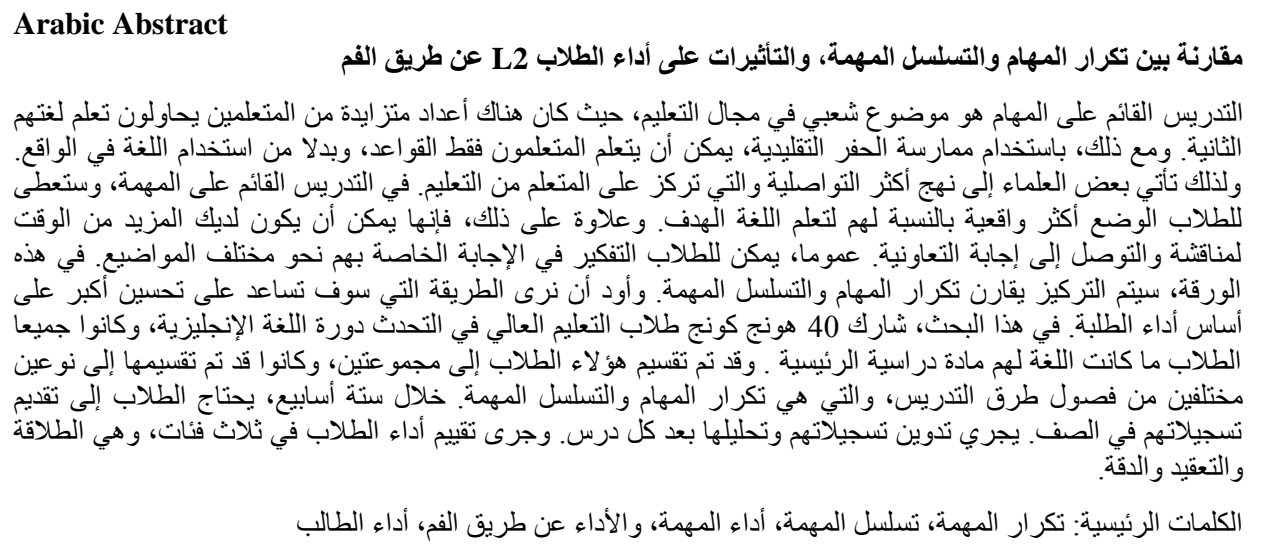

\section{German Abstract}

Vergleich zwischen Task Repetition und Task Sequenzierung, die Auswirkungen auf die S2 Studenten mündliche Leistung

Task-based Lehre ist ein popluar Thema im Bildungsbereich, da es eine wachsende Zahl von Lernenden versuchen, ihre zweite Sprache lernen. Doch mit der traditionellen Bohrpraxis, können die Lernenden nur lernen, die Regeln, anstatt die Sprache in der Realität. Daher haben sich einige Gelehrte mit einem kommunikativeren und lehrerzentrierten Lehransatz beschäftigt. In der aufgabenorientierten Lehre wird den Schülern eine realistischere Situation gegeben, damit sie die Zielsprache erlernen können. Darüber hinaus können sie mehr Zeit zu diskutieren und kommen mit einer gemeinsamen Antwort. Insgesamt können die Schüler ihre eigene Antwort auf verschiedene Themen denken. In diesem Aufsatz wird der Schwerpunkt auf die Wiederholung von Aufgaben und Task-Sequenzierung. Ich möchte sehen, welche Methode wird eine größere Verbesserung auf der Grundlage der Leistungen der Schüler helfen. In dieser Untersuchung wurden 40 Hongkong-Tertiärstudenten an einem englischsprachigen Kurs teilgenommen, und sie waren alle nichtsprachliche Hauptstudierende. Diese Schüler wurden in 2 Gruppen eingeteilt, und sie wurden in zwei verschiedene Lehrmethoden Klassen, die Aufgabe Wiederholung und Aufgabe Sequenzierung aufgeteilt wurden. Während des sechswöchigen Kurses mussten die Schüler ihre Aufnahmen im Unterricht einreichen. Ihre Aufnahmen wurden nach jeder Unterrichtsstunde kodifiziert und analysiert. Die Leistungen der Schüler wurden in drei Kategorien bewertet, die fließend, komplex und genau sind.

Schlüsselwörter: aufgabenwiederholung, tasksequenzierung, aufgabenleistung, mündliche leistung, leistung des schülers 


\begin{abstract}
Malaysian Abstract
Perbandingan antara pengulangan tugas dan penjujukan tugas, kesan ke atas prestasi lisan pelajar L2

Pengajaran berasaskan tugas adalah satu topik popular dalam bidang pendidikan, kerana terdapat peningkatan bilangan pelajar yang cuba untuk belajar bahasa kedua mereka. Walau bagaimanapun, menggunakan amalan tradisional, pelajar hanya mempelajari kaedah-kaedah, dan bukannya menggunakan bahasa dalam realiti. Oleh itu sebahagian ahli akademik telah tampil dengan pendekatan yang lebih komunikatif dan pengajaran berpusatkan pelajar. Dalam pengajaran berasaskan tugas, pelajar akan diberikan keadaan yang lebih realistik bagi mereka untuk belajar bahasa sasaran. Selain itu, mereka boleh mempunyai lebih banyak masa untuk berbincang dan memberikan jawapan yang kolaboratif. Secara keseluruhan, pelajar boleh memikirkan jawapan mereka sendiri ke arah topik yang berbeza. Dalam kertas ini, tumpuan akan membandingkan pengulangan tugas dan penjujukan tugas. Saya ingin melihat kaedah akan membantu peningkatan yang lebih besar berdasarkan prestasi pelajar. Dalam kajian ini, 40 pelajar pengajian tinggi Hong Kong telah mengambil bahagian dalam kursus berbahasa Inggeris, dan itu bukan bahasa pertama mereka. Pelajar telah dibahagikan kepada 2 kumpulan, dan mereka telah dibahagikan kepada dua kaedah pengajaran kelas yang berbeza, yang menggunakan pengulangan tugas dan penjujukan tugas. Sepanjang enam minggu, pelajar perlu mengemukakan rakaman mereka di dalam kelas. Rakaman mereka dianalisis selepas setiap pelajaran. Persembahan pelajar telah dinilai dalam tiga kategori iaitu kefasihan, kerumitan dan ketepatan.
\end{abstract}

Kata Kunci: pengulangan tugas, penjujukan tugas, prestasi tugas, prestasi lisan, prestasi pelajar

\title{
Russian Abstract \\ Влияние на Устное Исполнение Учащихся L2 Сравнения Повторения Темы и Распорядка Тем
}

На основе задач учений популярной темой в области образования, поскольку существует все большее число учащихся пытается выучить второй язык. Однако, используя традиционный буровую практику, учащиеся могут только выучить правила, а не с использованием языка в реальности. Поэтому некоторые ученые придумали более коммуникативным и личностно-ориентированного подхода обучения. В основе учений задач, студенты получат более реалистичную ситуацию для них, чтобы узнать целевой язык. Более того, они могут иметь больше времени, чтобы обсудить и выйти с совместный ответ. В обшем и целом, студенты могут думать о своих собственных ответов по отношению к различным темам. В данной статье, основное внимание будет уделяться на сравнивая повторения задач и задач секвенирование. Я хотел бы видеть, какой метод будет вести большее улучшение на основе студентов эффективностие. В этом исследовании, 40 Гонконгских третичного студентов были принимала участие в англоязычном разговорный курсе и все они были неязыковых крупных студентов. Те студенты были разделены на 2 группы и они были разделены на два различных методов обучения классов названных как повторение задач и задач секвенирования. В течение шести недель курса, студенты необходимый представить свои записи в классе. Их записи были кодифицированы и проанализированы после каждого урока.

Ключевые Слова: повторение задач, задача секвенирования, работы задач, устные производительность, производительность студента 